\title{
Community and the School: Elements for the Debate on the Indigenous Community School ${ }^{1}$
}

DOI: https://doi.org/10.32870/dse.v0i13.235

\section{Maike Kreisel*}

Translation by Marcela Suárez Essport msuarezessport@gmail.com Revised by Joshua Sol Lewis joshua.sol.lewis@gmail.com

\begin{abstract}
This article analyzes the experience of the Indigenous Community Secondary Schools of Oaxaca, Mexico, focusing on how alternative knowledge articulates with community and scholastic practices in everyday pedagogic activity. Although backed by official education agencies, the model emerged as a pedagogical alternative within Oaxaca's movement for a community education based on the philosophical and ethnopolitical proposal of the community. Based on a lengthy ethnographic study conducted in one of the 10 Indigenous Community Secondary Schools in a Zapoteco town in the northern sierra of Oaxaca, this article evaluates some of the contributions, problematics, and limits of the projects which aim to build educational processes based on the right of native peoples to participate in the creation of educational systems that respond to their cultural, linguistic, and ethnic interests.

The Community Indigenous Secondary Schools approach this goal through participation, dialogue, and cultural reclamation processes that seek to achieve greater curricular, social, and cognitive justice in a context of historical inequality, discrimination, and social exclusion. In its attempt to go beyond the integrationist and assimilationist educational practices that have characterized indigenous education in Mexico, the model faces numerous tensions, including those between the construction of alternative epistemes and the reification or essentialization of identity and culture, between the appropriation of what is "foreign" and the resignification of what is "ours", and those involved in the reflection on cultural hybridization. The articulations and resignifications of pedagogical, academic, and community forms become key in daily practice, as well as the flexibilization of learning spaces and times. Within this panorama, the model is successful in its search for more flexible, collaborative, and dialogic pedagogies. Key words: Indigenous education, interculturality, community participation, knowledges, justice.
\end{abstract}

\section{The Intercultural School, a Territory in Dispute ${ }^{2}$}

Since the creation of the General Board of Indigenous Education in 1978, indigenous education has been institutionalized as part of the official system of education in Mexico. However, the debate over the characteristics of an appropriate education for native peoples has continued from times of Indigenismo ${ }^{3}$ to this day. The issue still constitutes a complex field, with multiple competing perspectives that address processes of attention to diversity from different pedagogic, epistemic and political approaches (Jiménez Naranjo, 2012).

\footnotetext{
* Educational Research doctoral candidate, Universidad Veracruzana. E-mail: maike_k@yahoo.de

1 This work is part of the research project Community Indigenous Secondary Schools of Oaxaca-Resignifications of School Education from an Alternative Proposal for the Formation of Youth. Universidad Veracruzana, Educational Research Doctorate

2 Thanks to Doctor Yolanda Jiménez Naranjo, Director of the doctoral work in which this paper is based, for reviewing it and contributing opportune observations.

3 Name given to governmental policy with anthropological bases focused on the assimilation and integration of Indigenous groups into the nation-state. Three periods can be defined in Mexico: "Preinstitutional" during the Colonial era, "Institutionalized Indigenismo" following the Mexican Revolution (1910-1917) - with its formalization in 1948 with the creation of the National Indigenous Institute - and the current era (1982 -), which finds institutionalized Indigenismo in crisis due to neoliberal reforms, generating so-called Neoindigenismo (Korsbaek and Samano-Rentería, 2007, p. 196).
} 
It would be impossible to explore in this brief document the ins and outs of this debate. ${ }^{4}$ Nonetheless, it is important to stress that the model of Community Indigenous Middle Schools that we describe here is the result of a series of challenges to the historical assimilation forced on native peoples by the schooling process. The introduction of scholastic institutions in these communities historically has not helped ameliorate asymmetrical relations (economic, epistemic, power) to which they are subject to this day (Walsh, 2005; Viaña, 2008; Santos, 2009).

The Oaxaca Community Indigenous Middle Schools ${ }^{5}$ arise from a critical position which intends to go beyond classic mainstream education. The discursive underpinning of the proposal could be linked to another set of proposals (from Mexico as well as from other countries in Latin America) that seek to include the participation of community members in the definition of content and learning activities, incorporate native communities' autochthonous pedagogical practices, and accommodate the times and spaces of educational activities to specific communities' conditions and the rhythms of agricultural cycles. The link between school and community is fundamental; the proposal is "to establish as a fundamental axis the close relationship between school knowledge and family/community knowledge in an indigenous environment" (Jiménez Naranjo, 2012: 176).

There are proposals like the wixárika y na'ayeri schools network (De Aguinaga, 2010; Barba, Landey and Hernández, 2014) in Jalisco and Nayarit, the Telesecundarias Vinculadas a la Comunidad [Community Based Rural Middle Schools] (Pieck, Messina and Teaching Collective, 2008) in Puebla, UNEM's experience in the state of Chiapas (Sartorello, 2009; Bertely, 2011), the PRATEC initiatives in Peru for the creation of "a friendly school with local wisdom" (PRATEC, 2004), the experiences of the Mayan Educational Network which has pushed for, among other initiatives, an alternative education for the Mayan, Xinka and Garifuna communities in Guatemala (CNEM, 2013), and lastly, the network of schools fomented by the PROMIGAS Foundation in Colombia (Fundación PROMIGAS, 2010). Their educational proposals are not only pedagogical and curricular, but also political in the sense discussed above. These initiatives are promoted by members of academic institutions and NGO's as well as by indigenous and Afro-Mexican organizations, intellectuals, and citizens.

The educational practices in these proposals, however, are not free from tensions. They are couched in a complex socio-historical and political context that involves the trajectories of school actors, teachers and students, as well as the histories of native communities immersed in processes of acculturation, discrimination, racism and resistance in relation to mainstream society (Walsh, 2005: 32). These processes historically have been supported by a mainstream education whose aim

4 However, there are many documents that provide global or partial panoramas on these debates: (Cfr. Hamel, 2001; Jiménez Naranjo, 2009, 2012; Sartorello, 2009, Velasco y Jablonska, 2010; Bensasson, 2013; Dietz y Mateos, 2008, 2011; Martínez Buenabad, 2015).

5 Translator's note: "middle school" refers here to what is known as "secundaria" in Mexico, even though children in Mexico start the latter one year later than in the US. Children begin the "1st grade" of secundaria at the approximate age of 12, while those in the US begin "6th grade" in middle school at the approximate age of 11. Throughout this article "1st grade of secundaria" is translated as "6th grade", while "3rd grade of secundaria" is translated as "8th grade". 
has been to convert indigenous cultures to other lifestyles categorized by some as conducive to a better future. An undeniable influence has also been the inevitable dialogue with different sociocultural spaces, the appropriation of elements from other cultures, and a constant hybridization of social practices, all of these representing common transformations that result from the dynamic and re-articulating character of cultural processes (García Canclini, 2001).

Here we understand cultural appropriation as a permanent process "that is shaped by external or internal forces and leads to the creation or appropriation of a plethora of cultural assets of varying nature (material, organizational, knowledge related, symbolic, and/or emotive)" (Bonfil Batalla, 2004: 119). Through appropriation, some elements from other cultural contexts are integrated into a given culture. The social conflicts and power relationships which characterize interethnic dynamics and contexts play an important role in the articulation of these elements. Bonfil Batalla interprets these tensions in terms of a "struggle for cultural control"; in this sense they include innovation with one's own cultural assets and resistance to external elements (Bonfil Batalla, 1991:185). It is pertinent to acknowledge that cultural appropriation, although limited by the "coercive nature... of cultural heritage", involves "a sense of the active and transformative nature of the subject... [which] distinctly positions people as actors who appropriate and draw on available resources" (Rockwell, 2005: 29).

We posit that these tensions are also present in the processes of appropriation of scholastic institutions by native communities' alternative educational projects; they are as related to what interpretation is given to the discourse and practice of the intercultural and community approach as to the complex processes of cultural and identity reification and essencialization that may emerge within the projects. Such processes cannot be analyzed in a monolithic or univocal fashion (Jiménez Naranjo, 2012); they take form within the framework of native groups' resistance to mainstream society. Following Bonfil Batalla (1987), Dietz argues that "as a result of the 'ethnification' of cultural practices, the latter are constituted in a given group's 'own culture," in which "ethnic identity" is used as an instrument of empowerment (Dietz, 1999: 64). It is in this fashion that the appropriation of school institutions for empowering ends also becomes part of processes of ethnogenesis (Dietz, 1999: 65; Bertely, 2005; Apodaca, 2006).

In regard to these tensions, Jimenez Naranjo (2012) noted a challenge for alternative educational projects: the incorporation of processes of reflection at a meta-cultural ${ }^{6}$ level in order to analyze the form and degree to which cultural practices as such can be related to the school curriculum. We will discuss how in the case of the Community Indigenous Middle Schools in Oaxaca a dialogue with cultural practices is being established in the everyday activities of an educational proposal forged in close collaboration with the community and its knowledge, and which has the intention of going beyond the mere incorporation of folklorized cultural elements into the classroom.

6 Jiménez Naranjo understands the concept "metaculture" as "the process generated when we intentionally take culture as an object of reflection". These processes entail a deeper level of abstraction than cultural ones, without being for this reason identity-based (Jiménez Naranjo, 2012: 181). 
To that end, I present here some of the findings of an ethnographic study (Rockwell, 2011; Velasco y Díaz de Rada, 1997) conducted in a Zapotec community in the Sierra Norte of Oaxaca, which sought to understand how the practice of this educational model is articulated in a concrete context. I participated in daily school-related and community tasks during a lengthy stay in the community. The methods employed were participant observation, semi-structured and open interviews, and discussion groups. Additionally, I established a dialogue with academic and institutional actors associated with the proposal and with indigenous education in Oaxaca. A system of categorization (Díaz de Rada, 2011) was generated for data analysis, with the goal of establishing a dialectic process between the categories emerging from empirical data and the theoretical elements guiding their interpretation. To this end, periods of fieldwork were alternated with periods of systematization.

\section{Community Secondary Schools: An Alternative Proposal for the Education of Native Peoples}

The model of the Oaxaca Community Indigenous Middle Schools emerged as part of initiatives by the pedagogical movement of the Oaxaca Coalition of Teachers and Facilitators (CMPIO) for a meaningful and dialogic community education; it is the result of efforts by teachers towards dialogue with communities, academics, indigenous and non-indigenous intellectuals, and interested institutions. It is part and parcel of the push for community education in Oaxaca and the paradigm of Comunalidad [autonomous community-centered governance] as a philosophy and way of life of native communities in Oaxaca (Rendón Monzón, 2003, 2011; Martínez Luna, 2013; Díaz, 2007; Maldonado, 2010).

The model, validated through an agreement between Section XXII of the SNTE-CNTE [the Oaxaca teacher's union] and Oaxaca's Public Education Institute (IEEPO), began a pilot phase in 2004 in five schools; at present it is being applied in ten schools in different indigenous regions of the state. The model adopts a unique methodology which transcends the fragmentation of knowledge into distinct disciplines by fostering research and learning projects concerning relevant topics for the community and fomenting dialogue between scholastic content and community knowledge and practices.

Each grade of students is guided by an educator through formative processes directed towards collaborative and autonomous learning. ${ }^{7}$ The model seeks to strengthen the participation of parents and community members in school learning processes and decision making. In what follows we

7 Educators in the Community Indigenous Middle Schools come from different native communities in Oaxaca. Inasmuch as the model has only been recognized at a state level, it does not receive federal resources for a budget of its own, a situation which has worsened as a consequence of recent educational reform policies. Educators don't receive a salary according to the educational level they teach yet work on extended timetables due to the flexibility required by the projects. They are strongly committed to the objective of the model, even as they labor under a great deal of uncertainty due to present political tensions which jeopardize community education in Oaxaca. This is so despite the fact that that the model counts on the support of the PTEO and the recent Law of Education passed by the Oaxaca State Congress last April. This law recognizes the Community Indigenous Middle Schools as part of Oaxaca's official system of education (Article 16). 
will analyze practices observed in one of the ten schools. Our reflection revolves around two axes: the dialogue between knowledges and the conversation between scholastic and community pedagogical practices.

\section{Dialoguing with the Other and Resignifying the Self ${ }^{8}$}

The Indigenous Community Middle School structures its educational program around topics of local interest. The curriculum for each grade is defined processually based on research and learning projects; these projects seek to recuperate local knowledge in order to be able to establish a dialogue with academic subjects (ESCI/IEEPO, 2007). This logic implies an epistemological repositioning, a deconstruction of the traditional frameworks of mainstream education, which in general remain an essential part of modern Western discourse (López Pérez, 2004-205), ${ }^{9}$ even as the contextualization and situated meaning of the learning process is increasingly encouraged from the constructivist point of view (Lave y Wenger, 1991; Díaz Barriga, 2003).

In recent decades, in Mexico and other countries in Latin America, a critical vision of the epistemological underpinnings of education has been fomented, issuing not only from academic analyses but also from different innovative community and intercultural education initiatives. Within this perspective, special attention has been drawn to the quest for more cognitive justice (Santos, 2007: 53). Some Latin American authors have advocated recognizing the presence of a "colonialism of knowledge" (Castro-Gómez, 2000) in school environments, universities, logics of progress and social mobility, and in different areas of everyday life. In this respect, Daniel Mato argues that the tendency to dichotomize knowledge between "one who is a bearer of 'universal truths' and another who only possesses 'local truths,' is as old as the creed of the superiority of Western civilization" (Mato, 2008: 102).

Based on an analysis of research experiences in emerging educational projects, González Apodaca and Rojas point out that the "incorporation of community or indigenous knowledge into school teaching/learning processes and their articulation with conventional school knowledge" represents one of the biggest challenges for the future of intercultural education (González y Rojas, 2013: 292). The dialogue between different knowledge systems (Leff, 2004) implies, in practice, reformulating the educational practice of school as an institution, and for educators it implies

8 Bonfil Batalla argues that cultural elements are part of one's "own culture" when they have been received "as cultural heritage from previous generations" and continue to be produced, maintained and transmitted by a specific social group. External elements, on the other hand, "form part of the group's lived culture, but haven't been produced nor reproduced by it" (Bonfil Batalla, 1991: 7). Likewise Bonfil Batalla develops, as has been mentioned, the concept of cultural appropriation in reference to the integration of elements considered as external to a given culture. It is for analysis purposes that we adhere in some measure to a dichotomy between a group's "own" culture and external cultures, even as we are aware of the heterogeneity and hybridity of cultural processes. We recognize that "the use of the dichotomy, "own"/ foreign or local/global as categories that delimit identities, invariably conceals significant, non-explicit internal heterogeneity that is potentially conflictive" (González Apodaca, 2006:230).

9 López Pérez analyzes education discourse in Mexico, arguing that it "can also be read in the context of so-called modern Western thought, understood not merely as the religious and economic expansion of the West since the sixteenth century, but also as a hegemonic form of knowledge posited as the only way of interpreting the world" (López Pérez, 2004: 205). 
the development of new pedagogical knowledge. Tovar argues that this is not a simple matter of translation, since different traditions of knowledge originate in distinct rationalities, understood as "cultural systems of interpretation that reflect the notions and knowledge of social groups" (Tovar, 2009: 4-5). Knowledge, through collective practices in a specific context, becomes situated knowledge; thus one can speak of a plurality of epistemologies (Tovar, 2009: 6).

A central question would then be how to create spaces conducive to the development of pedagogical practices that might allow dialogue between "indigenous knowledge as it is lived and practiced in the community and mainstream school content as a whole" (Gasché, 2004: 198), without losing sight of the contexts from which they respectively come and taking into account the genealogy of each discourse (Dietz y Mateos, 2011: 121). Rengifo argues that this dialogue of knowledges must be carried out with the explicit understanding that "school knowledge belongs to a view of the world that is different than that of the Andes, and the relationship between the two should always refer to equivalence rather than hierarchy" (Rengifo, 2003: 113).

A tendency of educational practice - and even of academic discourse, as has been shown by Dietz and Mateos (2011) - is the dichotomization of knowledges, that is, their conception as two separate entities and a corresponding tendency towards their reification. Dietz and Mateos argue that for native groups this dichotomy might be convenient in political terms as well as encouraged by geographic distances from urban spaces in which many native communities are settled (Dietz y Mateos, 2011: 134). In this sense, the articulation of knowledges represents a challenge of interpretation and strategy creation for educational actors.

Research on the model of Indigenous Community Middle Schools showed the tendency of actors to define the role of the community schools in terms of rescuing their native culture, which is perceived as historically threatened by processes of acculturation.

\footnotetext{
"It's about rescuing, of working very hard on community knowledges, because many things are being lost in many places... from there priority must be given to our community's way of being because this belongs to us, it is something inherited from our ancestors that has always been practiced" (E-Elena-educator).
}

In the context of experiences of ethnic discrimination, urban or mestizo influences are sometimes analyzed in the community schools in terms of their disadvantages as compared to the cultural practices considered native to the community, which are seen to be at risk of being displaced. We interpret this tendency as part of resistance processes in the context of asymmetric relations between cultures, which implies the necessity of vindicating what is "native" against what is "foreign". In the following example, students contrast community and urban spaces:

"In the community they say that our way of thinking is different to that of the city. Why? Because in the city
they don't take as much care of the environment, while in the community they take care of and optimize 
Community and the School. Elements for the Debate on the Indigenous Community School

the use of nature, like plants and animals; in the community they consume what they grow. Corn and beans, for example, are the most common crops. In contrast, people in the city only think of having more money at the cost of damaging nature. With the passing of the years, there have been many changes in the way of thinking in the community. For example, if we compare the way of thinking of an old man with that of a young person the result would not be the same. These changes are due to the ideological pollution which is taking place in our community (Research work document - fourth generation).

The Indigenous Community Middle School aims to strengthen native cultures and identities; ${ }^{10}$ comparisons between certain autochthonous and foreign cultural practices tend to ethnify the former as part of an attitude of indigenous empowerment. In this regard, Richard proposes the concept of "identity through opposition", a process in which a dichotomy is made between an "us" and "the others" in relation to specific characteristics (Richard, 1993: 212). Escárcega emphasizes the political weight of the strategic essentialization of identities as part of native peoples' struggle for more social justice (Escárcega, 2009: 43). A risk of essentialization would be to overlook the diversity within a cultural group (Dietz, 2013: 179). However, in our case we perceived how student and teacher analysis of community culture does in fact take into consideration processual and generational changes, rather than holding a static conception of the culture. In this case such changes are perceived as a "contamination" of native culture due to the bias implicated in the fostering of an attitude of Indigenous empowerment.

In terms of the approach to a dialogue of knowledges, Escárcega recommends starting with the recognition of one's own culture in order to then consider the appropriation of other cultural elements (Escárcega: 2009: 43). This appropriation calls for a critical analysis of the genealogy of the discourse of the "other" knowledge in question, in this case the specific knowledge that is being brought into dialogue, which includes the contents of official middle school education. For example, the Indigenous Community Middle Schools hold day-long history activities on the occasion of historic holidays on the official school calendar, but try to question the perspective of dominant historical narratives by investigating underlying power relationships and social asymmetries. In this manner, one of the educators points out to students that "it is the hidden story that has to be looked into, because indigenous people have always been repressed" (Observation $-8^{\text {th }}$ grade classroom). On these history days students are expected, following the methodology of the model, to generate questions concerning Mexican Independence.

10 We based our understanding of the concept of culture upon authors like Rogoff, Moore, Correa Chavez and Dexter, who understand culture in terms of "repertoires of practice". This conception brings us to a notion of culture as experiences lived by persons throughout their life through the same social practices, immersed in the same community history (Rogoff et al., 2015:491). Giménez points out that nevertheless, "culture must never be understood as a homogeneous, static and unmodifiable repertoire of meanings" (Giménez, 2009: 10). Culture, in this manner, is transformed, subject to hybridizations through cultural contact. On the other hand, we understand identities as "internalized cultural repertoires... through which social actors (individual or collective) mark out their boundaries and distinguish themselves from the other actors in a given situation, all of this within a space historically circumscribed and socially structured" (Giménez, 2000:54). We understand that identities are not built from permanent attributes but they are processual and plural; in this sense, Dietz proposes a perspective "of diverse character, plural, multi-situated, contextual, and therefore necessarily hybrid of cultural, ethnic, class, and gender identities" (Dietz, 2013: 184). 
Educator Carlos and students review the questions on the history of Independence which they began elaborating the day before as part of the "problematization" of this historic episode. New questions are generated as they go along.

Isaac: Teacher, who wrote the laws of Mexico?

Carlos writes the question on the blackboard

Irina: How many people were there fighting in the war?

Eneida: How many people died in this war?

Carlos keeps writing: Who invented this tradition of celebrating America? What does it mean?

Isaac: Why don't citizens want to investigate this?

Ingrid: Why don't they tell the truth about how the Revolution really was?

Carlos writes: Why is the true history hidden?

Isaac: That's what I meant to ask

(They write)

Carlos writes: What conflicts were there from 1810 to 1920 ?

Ingrid: Who were the most affected?

Carlos writes: What were the effects of Mexican Independence?

The students keep copying from the blackboard.

Carlos: You are going to analyze this. We'll be supporting you, but no more. You will start writing your reflexive texts. This requires student intelligence. It is your own reflection. We will not dictate nor will you copy from the book. You will make your own reflections. Is that clear? This is not a game. This includes the "Cry of Dolores" and the Querétaro conspiracy (Observations - 8th grade classroom).

The ethno-political dimension expressed in the analysis of different knowledges is outlined not only by the educators' classroom discourse, but also in other community spaces. Beyond this critical analysis, dialogue with other types of knowledge turns out to be extremely relevant for members of the community, since the imperatives of their environment call for youth to be familiar with a diverse knowledge set.

I think that this is good because in this school they rescue the customs of the community, the practices and customs passed down by our ancestors. And for example, now students are not only learning what is new, what is going on at the present, but they are also rescuing what was being lost from our grandparents (Interview - community secretary).

The proposition of cultural recovery tends to locate the knowledge of native cultures in the past; it is associated with the culture of community elders, which indicates that the culturally derived notion of the value of community experience is still in force. This experience is acquired by 
community members through local practices of production, organization, and health, to name a few, and constitutes a source of knowledge for new generations to learn. ${ }^{11}$

On the other hand, the tendency to associate "our culture" with the past is seen by some authors as another process of essentialization. In analyzing the strain of indigenous thought known as comunalismo ["communalism"], Dietz points out how in some cases the discourse of communalism tends to overlook the heterogeneity which is present in every social group and reduces "local 'intraculture' to what is ancient, traditional, or 'authentic" (Dietz, 1999: 356). For Dietz communalism represents a model of indigenous empowerment which "attempts to strengthen and give priority to endogenous resources ... against the imposition of exogenous, colonizing models" (Dietz, 2013: 179). Fernández and Estrada, following Trollinger (2012), allude in this sense to a nostalgia for the past and for what has been lost as part of the substantialization of a community's culture, which we find present here, especially in the discourse of elder community members, but also, in some cases, in that of educators and middle school students (Fernández y Estrada, 2014: 20).

Dialogue with external elements, however, has also become necessary and convenient. Conditions of horizontality are the goal, a delicate balance in the face of the influences of migration and technology and other factors which have made the boundaries of the community more porous to other type of spaces beyond it. The latter entail transformations in cultural and identity processes and practices which are most evident in younger generations that are more open to learning from and being in contact with the world, for example through social networks. Silva states that "formal education and school constitute only one of the spheres in which social identities are built ... the cultural and the social are also pedagogical and curricular dimensions" (Silva, 1997: 5). In this sense, learning occurs in different spaces and dimensions which dovetail with how identities are defined.

These gradual changes concern all generations and require that the community school become a dialogic space. The concept of meta-culture mentioned by Jiménez Naranjo (2012) explains how the dynamics of collective reflection generated in community school research projects can foster the construction of knowledge concerning the logics of the transformation and hybridization of cultural practices. Educators emphasize the need to incorporate reflection as a formative practice which will gradually foment reflexive processes in the community sphere. They see the community middle school as "a space of reflection of this community knowledge" which is beneficial for the community, since "maybe people in the community don't reflect, they just live; now, with this school, this type of reflection is happening" (Educators' discussion group). We can observe how these processes are fostered in everyday practice.

11Diaz (2007) also uses the term community-members/citizens. Community belonging is defined as much by citizens' rights as by the fulfillment of obligations (Maldonado 2010). 
Conrado asks students to share the conclusions arrived at in teams. One of the teams has to bring them all together.

Eneas reads from his notebook in Spanish about roads and consumerism, saying that the latter already existed before in a certain way through the merchandise that was brought by pack animals. The new road changed everything, leading to the incursion of businesses and environmental pollution; natural products are not used like before.

Conrado: Now let's hear from Esteban's table

Esteban: Great benefits, great consequences. There was no pollution of any kind here, [only] the benefits of plants; they manufactured tools... contamination and consumerism cannot be avoided any more... they could be reduced, but first people have to understand that by consuming these products they are contaminating our community.

Aristeo: They brought products and clothes. We used to consume quelites and other plants; now these kinds of quelites are disappearing because they aren't cultivated anymore and people don't eat them...The road is beneficial for those who have to go out of the community to work; those who are adversely affected are the ones who stay and work the land.

Melanie: In 1984 they destroyed the trees, and because of this the land got more and more polluted.

Conrado: You are going to work on your proposals, though it was not part of the plan. In area number 1 you will work on your proposals in groups, proposals that respond to what you've talked about. Yesterday you mentioned that community values are being lost, which also has an effect on the environment, there is a lack of respect. What do you propose? What should be done? (Observations - 8th grade).

Based on these projects, community middle school students observe their context and analyze community practices, thus becoming aware of historical processes and noticing changes that have taken place. What is implicitly presented through the projects is an understanding of culture as practices in constant transformation and in dialogue with a wider context.

For the people in this community, culture means traditional local celebrations which have been observed in the past and continue to be observed every year. There have been many changes in the celebrations. For example, the musicians used to play drums and flutes in the celebration, but the music is now played with other instruments ... The culture of our ancestors is not the same as the one we have today. Culture is everything the people living together in a community do (Written work - 8th grade).

Awareness of cultural change is reflected in different projects. For example, one research project designed by educators in conjunction with students dealt with community technology, analyzing historic and contemporary transformations and taking into account the appropriation of external elements (Bonfil Batalla, 2004; Rockwell, 2005) through the classification of observed technologies as "pre-Hispanic, assimilated and modern" (Observation - informal conversation with educator). 
The deepening of community knowledge by educational actors in dialogue with other knowledges or cultural practices implies, according to the model, confrontation and reflection: "confrontation of one's own reality with other realities and the possibility of finding convergences and divergences, as well as familiarity and application with middle school curricular contents" (ESCI/IEEPO, 2007: 19). According to one of the school advisers, a Zapotec author and long-term participant in the model, ${ }^{12}$ it is the reflection on different types of knowledge which will result in the construction of knowledge.

Confrontation is how we are going to understand respective knowledges, how one is similar to the other, where each type of knowledge leads, what each knowledge seeks to do for human beings. From this reflection a construction will arise (Interview -HMS-adviser).

The process of meta-cultural reflection implies an inquiry into the historical, socio-cultural and ideological contexts from which different knowledges issue. The analysis of knowledges from their respective backgrounds is perceived as the possibility of the construction of a new type of knowledge. We observed how indigenous middle school students try to examine their community's productive practices in this sense. They analyzed how the industrial processes underlying the use of an iron mill might affect community members' "quality of life" (Mato, 2008).

We want people to recover community technology, like the wooden mill, for example... Why is it being brought back? ... What if in the iron sugar mill chemical products such as oil are being used? The oil then mixes with the sugar cane juice and then the product won't be one hundred per cent natural. That's what we want to recover (Group discussion - 8th grade students). ${ }^{13}$

The model sees the reflection and learning involved in this dialogue of knowledges as a process that makes a different outlook on the future possible.

But if you are not reflecting nor sitting down to reconstruct, then what you are doing has no future... If you don't do this you are not working for the future, you are anchored in the same place (Observation - HMS course-adviser).

\footnotetext{
12 I thank Hugo Miranda Segura for his contributions and shared reflections, which have been an invaluable contribution to my understanding of the complexity of community wisdom and the implications of a dialogue of knowledges.

13 The wooden sugar mill is built by community members from local materials and products; we can observe that it is a cultural object, as is the sugar cane, of external origin but "which ceased to be external and came to form part of the local culture". There has been an appropriation of the object, its meaning and the capacity to build it; it is a legitimate part of "our culture" (Bonfil Batalla, 2004: 124). The iron mill, in contrast, is a tool that some community members have recently acquired and brought to the community in order to facilitate the production process; it is considered an external object, since it has not undergone the same process of local adaptation and requires external supplies and components.
} 
This approach of looking at one's own culture and considering it in relation to external elements in a constructive sense can be observed in the reasoning of these students, who become aware that they can contribute to a reflection on the future of their community through these research projects.

Because this is a project that we chose, because we wish to be able to study, and because it is the most important thing for the community that might be useful for the future (Observation-record-student classroom meeting).

In practice, the dialogue, as we have mentioned, is not free of the tendency towards essentialization which involves different levels of value judgments, above all due to the need to vindicate one's own culture, but also due to the comparison with the external as something from which one's culture has generally been excluded. In this search for intercultural dialogue, therefore, conflict appears as a reflection of tensions which native communities face in their daily life. These tensions are generated from the processes described above: the cultural assimilation historically pushed by governmental entities and mainstream society, as well as asymmetries in terms of poverty and exclusion as part of a structural discrimination attended to by welfare and assistance programs.

And, finally, there are the influences of a changing world and contact through media with the trends of global development, as well as a series of interactions with other social spaces due to migration and the introduction of products and consumption practices from industrialized society, to name just a few factors. A key point is how these tendencies come to bear on community expectations for schools and the future of its youth, expectations which include aspirations - justified and fair and not at odds with a reappraisal of their own values - to be included in the national and global world, to have possibilities of getting a well-paying job, and to have recognition of scholastic, social, and economic achievements under equitable conditions.

This complex situation has entailed the need for community reflection on what constitutes desirable learning for indigenous community schools students in contrast to the socially legitimized model of mainstream classic schooling; it has also led to reflection on the viability and usefulness of "learning one's own culture", as well as the reassessment of community practices and knowledges by the younger generations. This contextual hybridity, even at a great distance from the state capital and the big city environment, emerges as a highly significant dimension that requires constant updating and permanent attention by the actors involved in an innovative educational model such as the Indigenous Community Middle Schools, who must always keep in mind the methodological and pedagogical underpinning of a proposal that emphasizes the dialogic and participative nature of learning. In the context of these sociocultural configurations, it is also necessary to be aware of how the link between school and community and dialogue between cultural practices concerns multiple vectors. In this case, we'd like to go back to the dimension of pedagogical practices. 


\section{Approaches to the Dialogue Between Community and Scholastic Pedagogical Practices}

The dialogue between school and community is not limited to what in general is considered as content, but rather encompasses a variety of interrelations and practices that constitute an important way of linking to and reappraising the meaning of interculturalism in education. Among these practices of interrelation between school and community culture, there are some that take place which don't constitute explicit strategies, but rather, in accordance with Jiménez Naranjo (2009), can be termed "clandestine". Learning is built in these interstices of everyday life, albeit in somewhat unusual or discontinuous forms (Roy, 2003: 13). Other forms of linking are intentional, as the model aims to foster a new articulation between school and community spaces, overcoming their historical division.

We will analyze below the manner in which the conception of culture can be reconsidered as a set of social practices in relation to the pedagogical forms observed in the educational activities of the Indigenous Community Middle Schools. This articulation is not always present in daily school life, but it is intertwined in the configuration of the practices of some of the educators. On one hand it emerges from the pedagogical objectives of the model, and on the other, it is spurred by the life trajectories of the educators who themselves come from native communities.

In community and family life, children's participation in family activities as part of the learning process entails the development of an early autonomy, with successive responsibilities and duties forming part of their socialization and gradual integration into community and family dynamics. Bertely, Saravi and Abrantes report that indigenous adolescents in general are more autonomous but not necessarily detached from their social context; they participate in a responsible way, "assuming new rights and obligations related to collective entities such as the family or community" (Bertely, Saravi y Abrantes, 2013: 16).

In the context of the Zapotec community where our research took place, we observed how community school students involve themselves in their families' everyday tasks. They do not detach themselves from the social and productive activities that form part of the community's processes of socialization. In order to allow for the continuity of this participation and transcend the disruptions made in the community's learning process by mainstream education, community school educators try to adjust school schedules to a certain extent, as well as interrelate local and non-local knowledges. This openness brings forth a dialogue between school and community learning spaces, and enhances a meaningful learning of the topics addressed in the school.

When Ingrid, Lara, and Isaac were making panela (raw cane sugar), they came to ask for permission to be out one day. I asked them, "How many days will you be working with the panela?" They said the whole week, so I told them to take the whole week then. They wrote their texts there while working on their farms; in the end they wrote a family report. We would visit the ranches in the afternoon and we could see that they were working (Group discussion - educator). 
Bertely analyzes the relationship between the socialization processes of a Mazahua community and teaching and learning dynamics in an elementary school. In this article we will take up one specific finding of that study, related to the link between school and community: the non-directional quality of classroom work. The author points out the realization of "parallel activities... without too much control by the teacher", thus applying "non-centralized" teaching strategies (Bertely, 1992: 107-108). In this fashion, the educator either applies community socializing strategies or these take place unintentionally.

A characteristic of Indigenous Community Middle Schools is the encouragement of autonomous student work. This is a new dynamic for students, since throughout previous grades - preschool through elementary - teaching is structured in a more vertical fashion. In the pedagogical practice of the community school one can observe how students are encouraged to gradually assume responsibility for their learning. The permanent presence of the teacher in the classroom is not necessary; once tasks have been clarified, students work collaboratively on different activities at their own pace. Educators provide orientation when required.

The kids are working on geography. Apparently the students are grouped by tables and the educator Conrado asks them to say the coordinates of the two countries they selected. Two maps are hanging on the blackboard, one of the continent of America and the other of the rest of the world... Alexander replies to Conrado in Zapotec when the latter says something to him in Spanish. The three girls (except Nadia) are reading what seems to be a short story in Spanish amongst themselves; they take turns reading aloud. Conrado leaves the classroom. It's Guadalupe's turn to read. Conrado comes back to the classroom with a notebook and sits down without interfering with the students' dynamic. Claudio and Lalo speak in Zapotec about the Atlantic and Pacific oceans. Lalo says something in Zapotec to Alexander. Ismael is looking over a white page with a map drawn on it. Nadia takes her map to Conrado and asks him something. Conrado explains something to her about the coordinates on the map (Observation $-{ }^{6 \text { th }}$ grade classroom).

As part of their development as autonomous learners, educators encourage students to resolve the questions that emerge from their research by themselves; they give few explanations or direct responses, in the belief that the student must actively construct his/her own learning and that project and research-based tasks are learned through practice.

Student: When he explains, he almost always does it only once. In elementary school they repeat and repeat and ask, "Children, did you understand?" We respond yes or no, and if the answer's no, they explain again until we understand, because they say it is necessary. The teachers have to explain so that we can keep learning more.

Researcher: And now the teachers no longer explain so much.

Student: We have to do it ourselves; we have to investigate and write the text by ourselves (Interview, Barbara - 6th grade). 
In the community and family context we see that learning processes in early childhood take place through a similar dynamic. Active participation in family tasks is not ordered directly, but rather learning and participation take place by the children's initiative, based on observation and imitation of other family members immersed in their daily duties and itineraries.

When I arrived and asked, "Are you picking corn off the cob?" The young woman said, "Making good use of time", and Mrs. Estrella (the grandmother) commented that she was also setting an example for her daughters. While observing the scene, I noticed that the small girl (4 years old) was absent-mindedly picking grains off the corncob with her small hands and putting them in a plastic washbowl. Every so often she would take more corncobs from a white sack. I asked the young mother if she had taught her daughter to do that and she answered no, she had never told her anything, that she had learned just like that. The mother added that the 4-year old does the same thing when they work with coffee beans, that she starts to imitate without anyone telling her anything. I said that she does it because she observes the others doing it, to which the mother agreed (Observation - Mrs. Estrella's house).

Although in community school practice tensions arise in relation to students' previous school experience, we saw how some educators, natives of other Zapotec communities and with substantial experience in the model, are able to establish a certain degree of continuity to community forms of learning. They generate student-centered dynamics of interaction both inside and outside the classroom in order to encourage more autonomous learning processes. Since educators understand student development in these new habits as a process, they are patient and try not to force student participation.

Educator Conrado scheduled rehearsals for the whole theater and dance program in the yard. The students were very distracted. Conrado was very patient, he didn't force anything. He called out, "1 1 st call, second call", but only some of the students came to participate... Conrado told one of the girls that he was available to help, but that their participation was up to them. He told me that when his 8th grade students were just starting the program in 6th grade there were also some of them who had trouble focusing. It was a gradual process to get them on board little by little. Now that they've reached the $8^{\text {th }}$ grade the result of the process is that everything is lot easier for him, students work very independently (Observation - yard).

The decentralized dynamics of learning processes in community school practice emerge with a certain degree of tension; contradictions arise in everyday educational tasks and doubts are voiced by the community in regard to the pedagogical model. Of the different factors that come into play, one that is particularly relevant is the imaginary of school education that has been socially internalized and is reflected in the discourses of different actors and even in the trajectories of educators trained in traditional institutions. 
Another factor is found in the significant importance given to respect in Oaxacan community relations (Martínez Luna, 2010), a value that traditionally mediates community social interrelations and manifests specifically in the treatment of elders as guardians of experience. This type of respect has been affected by the influences of contact with other cultural spaces through urban migration and media, as well as schooling itself. It is in this framework that we can interpret the perspectives of some parents towards community school dynamics.

Since the teacher is not in the classroom the students are happy, fighting amongst themselves, playing. They're not learning anymore, they don't stay in the classroom, they go out... now that there's not much discipline either (Interview - Eréndira - mother).

In practice, students and educators navigate learning spaces in dialogue with community knowledge through interviews of "community knowledge holders", thus regaining traditional forms of intergenerational oral transmission of knowledge (Briseño, 2015), as well as observation of the practices in the spaces where they take place. The act of allowing formative activities to transcend school space contrasts with classic schooling (Tyack and Cuban, 1995). Although we interpret this flexibility positively in terms of a dialogue between practices and situated learning (Lave and Wenger, 1991; Sagástegui, 2004), it is perceived as problematic by some community members.

They go about researching, going from one house to another, making trouble, a lot of trouble. They should be in the classroom, they should learn Spanish, arithmetic. And they speak only Zapotec, even with the teachers. They hardly speak Spanish (Interview - Eréndira, mother).

The traditional idea of school internalized by many is associated with access to the knowledge that has been legitimized by mainstream society and teacher-directed, in-class learning through textbooks. The elementary school experience of many fathers and mothers was defined by the authoritarian logics of assimilation and cultural integration policies. Rigid discipline and discrimination through the exclusion of native language from school spaces stand out in their narratives.

When I went to elementary school, you couldn't skip school, you couldn't be late, because the teachers would punish you, they would hit you with a small stick. When my children went to school that didn't happen anymore. The teachers did not want us to speak Zapotec, only Spanish. If you spoke Zapotec you had to pay 50 cents (Interview-Griselda-family mother). 
It is important to emphasize that the Indigenous Community Middle Schools intend to contribute to a process of deconstruction of historic experiences of exclusion and discrimination as well as of the importance given to school education by a centralized national curriculum. In contraposition to the mainstream model, the community schools propose more flexible, communicative, and collaborative pedagogies which allow for a local resignification of school and the strengthening of community culture by way of a necessary dialogue between what is "native" and what is "foreign".

\section{Conclusions}

In the context of historically formed, asymmetrical intercultural relations and a society riven by exclusionary, unequal condition, the experience described above represents an important effort to formulate and put in practice an educational proposal that not only puts the dialogue between school and community front and center, but that also seeks to generate, through practice, resources for a necessary conversation with other cultures, and particularly with mainstream society. In this manner it joins the debate concerning interculturalism in education based on a reassessment of the paradigm of classic schooling (Tyack and Cuban, 1995). The community schools propose a flexible curriculum that is articulated in tune with community needs, voices and practices, in such a way that learning contents come to reflect the socio-cultural processes, varied problematics, and tensions between "local" and "foreign" that community members face.

In positioning itself in terms of the empowerment of local epistemologies and a horizontal dialogue with mainstream disciplines, the model encounters the difficult exercise of articulating knowledge and practices that come from different socio-cultural contexts and have different rationalities. Through research projects that structure learning activities procedurally, learning processes that create links with student experience, community history and daily practices are generated. The model also leads students to observe and generate questions about their context. This closeness to the surrounding world creates meaningful learning for students and the community.

The relationship between the model and community expectations, however, is marked by certain tensions. On one hand, one can observe the desire for empowerment of native culture and identity; on the other, parents and youth demand an adequate education that can enable them to face the challenges of contact with different social realities and give them the possibility of horizontal participation - academic, occupational and social - in mainstream society. Processes of hybridization, cultural appropriation and resistance throughout community history constitute a context of learning that does not allow for linear educational approaches. They call for the sensibility to dialogue with actors' concerns, interests, and imaginaries as well as with the generational gaps that are ever more present due to the influence of the media, the internet, and television, to name a few, which are a source of learning for children and youth. Attention to emerging concerns and plural identities, without undermining the care and continuity of local cultural practices, is a complex imperative in the construction of an alternative school. 
This calls for cultivating youth capable of acting in a constructive way in their social reality, a task that involves different dimensions. Apart from a repositioning of the importance and relevance of local practices by reflecting on and analyzing community knowledge, what must be contemplated as well are the problematics and necessities that characterize a given context as a space of communication. The community schools show us how school should open itself up to the surrounding world, local and beyond; this requires a complex analysis of context and cultural processes, a challenge that mainstream schools have largely failed to meet in their attempts to establish intercultural curricula (Jiménez Naranjo, 2009, 2012).

The Indigenous Community Middle Schools provide guidelines for reflection concerning new continuities and necessary articulations between school and community: not only between community and scholastic learning, but also between culturally shaped family pedagogies and teaching strategies. This link between practices encourages students not to detach from their environment and softens the ruptures introduced by school education in the socialization processes of native communities.

The educational approach of this alternative proposal is not dissimilar from current discourses of teaching towards autonomous learning, problem solving, interdisciplinary research, education for life, participative citizenship, and diversity. What we must not lose sight of is the undercurrent of social exclusion and the historical processes of marginalization that give an important political positioning to the educational task of this - and other - alternative models.

Thus the dimension of meta-cultural reflection on cultural and social processes that is encouraged in the community schools bears the potential of critical analysis of the social phenomena observed during research, of scholastic discourse and content, and, of no less importance, of practice and discursive nature of the model itself as an educational proposal that stands out as an example for many actors in indigenous education in Oaxaca.

One of the contributions of the model is its bid for the permeability of school regarding the inter-cultural dynamics that surround it and in which students, parents, and the community itself are immersed. In this sense it also recognizes the plural, conflictive, and contradictory dimensions of social reality. In light of these vectors, a more flexible, dialogic, and collaborative pedagogy is significantly valuable. The Oaxaca Indigenous Community Middle Schools invite us to rethink school as a constructive space, interactive with its context and actors, and thereby generating pro-

posals that encourage relevant and necessary learning for youth as members and future citizens of their communities and societies.

\section{Bibliography}

Barba, A., R. Landey, and O. Hernández (2014). La alternativa educativa intercultural wixárika. In: Luengo, E. (coord.). Las alternativas ciudadanas para otros mundos posibles: pensamiento 
Community and the School. Elements for the Debate on the Indigenous Community School

y experiencias. Guadalajara: ITESO. pp. 53-70. Retrieved from: http://formacionsocial.iteso. $\mathrm{mx} /$ documents/10901/0/Complexus +5+noviembre/2e1e4f7b-4788-4d9c-a6cb-7f531c5943c5

Baronnet, B. (2009). "Autonomía y educación indígena: Las escuelas zapatistas de las cañadas de La Selva Lacandona de Chiapas, México". Doctoral thesis. El Colegio de México and La Sorbonne University.

Bensasson, L. (2013). “Educación intercultural en México ¿por qué y para quién?” In: Baronnet, B. and M. Tapia (coords.). Educación e Interculturalidad. Política y políticas. Mexico: UNAM/ CRIM. Retrieved from: http://www.libros.unam.mx/digital/V7/51.pdf

Bertely, M. (1992). "Adaptaciones docentes en una comunidad mazahua". Nueva Antropología, (42). Mexico.

(2005). “AApropiación escolar o etnogénesis? La escuela federal y socialista en una villa zapoteca mexicana (1928-1940)". In: Sociedad Mexicana de Historia de la Educación. Memoria, conocimiento y utopía. Mexico: Pomares.

— (2011). "Aprendizajes, (inter) aprendizajes, (re) aprendizajes y (des) aprendizajes al tejer una red de cuatro puntas. De cómo se vive la interculturalidad al pescar conocimientos y significados indígenas y comunitarios". In: Bertely, M. (ed.). Interaprendizaje entre indigenas. De cómo las y los educadores pescan conocimientos y significados comunitarios en contextos interculturales. Mexico: CIESAS-UPN, pp. 9-38.

— G. Saraví and P. Abrantes (2013). Adolescentes indígenas en México: derechos e identidades emergentes. Mexico: CIESAS/UNICEF.

Briseño, J. (2015). "Entrevistas comunitarias, la recuperación del conocimiento comunitario desde la escuela. El caso de las Secundarias Comunitarias Indígenas, Oaxaca, México". Archivos Analíticos de Políticas Educativas, 23 (95). Retrieved from: http://dx.doi.org/10.14507/epaa. v23.2081

Bonfil Batalla, G. (1991). "La teoría del control cultural en el estudio de procesos étnicos". Revista Estudios sobre las Culturas Contemporáneas IV (12) 165-204. Mexico: Universidad de Colima. Retrieved from: http://www.redalyc.org/pdf/316/31641209.pdf

— (2004). "Pensar nuestra cultura". Revista Diálogos en la acción, primera etapa. Mexico: Dirección General de Culturas Populares e Indígenas. Retrieved from: http://www.ilam.org/ ILAMDOC/sobi/Guillermo\%20Bonfil_Pensarnuestracultura-Pat.pdf

Castro-Gómez, S. (2000). "Ciencias Sociales, violencia epistémica y el problema de la 'invención del otro"'. In: Lander, E. (ed.). La colonialidad del saber: eurocentrismo y ciencias sociales. Perspectivas latinoamericanas. Buenos Aires: CLACSO, pp.145-161.

CNEM (2013). Educación propia: Pueblos Maya, Xinca y Garifuna. Lineamientos de construcción de políticas y de diseño y aplicación curricular. Guatemala: Ajpop Mayab’Tijonik CNEM. Retrieved from: http://www.infoindigena.org/images/Publicaciones_generales/Educacion/ Port_Educacion_Propia.pdf 
De Aguinaga, R. (2010). Tatuutsi Maxakwaxí. Una experiencia indígena de educación autonómi$c a$. ITESO: Guadalajara.

Díaz, F. (2007). Escrito. Comunalidad, energía viva del pensamiento mixe. Mexico: UNAM.

Díaz Barriga, F. (2003). "Cognición situada y estrategias para el aprendizaje significativo". Revista Electrónica de Investigación Educativa, 5 (2). Retrieved from: http://redie.ens.uabc.mx/ vol5no2/contenido-arceo.html

Díaz de Rada, A. (2011). El taller del etnógrafo. Materiales y herramientas de investigación en etnografía. Madrid: UNED.

Dietz, G. (1999). La comunidad purhépecha es nuestra fuerza. Etnicidad, cultura y región en un movimiento indígena de México. Quito: Abya Yala.

and L. Mateos (2008). "El discurso intercultural ante el paradigma de la diversidad: estructuraciones subyacentes y migraciones discursivas del multiculturalismo contemporáneo". In: Bastos, S. Multiculturalismo y futuro en Guatemala. Guatemala: FLACSO/OXFAM.

— (2011). Interculturalidad y educación intercultural en México: un análisis de los discursos nacionales e internacionales en su impacto en los modelos educativos mexicanos. Mexico: CGEIB.

(2013). Comunidad e Interculturalidad entre lo propio y lo ajeno: hacia una gramática de la diversidad. In: Baronnet, B. and M. Tapia (coords.). Educación e Interculturalidad. Política y políticas. Mexico: UNAM/CRIM. Retrieved from: http://www.libros.unam.mx/digital/V7/51. pdf

Escárcega Zamarrón, S. (2009). "Trabajar haciendo: activist research and interculturalism”. Intercultural Education 20(1), pp. 39- 50.

ESCI/IEEPO (2007). Secundaria para la atención de comunidades pertenecientes a los pueblos originarios en el estado de Oaxaca (versión sintética). Oaxaca: ESCI/IEEPO.

Fernández Repetto, F. and I. Estrada Burgos (2014). Esencialización y espectacularización de lo maya. Turismo voluntario y étnico en una comunidad yucateca. Península [online]. 9(1) 9-32. Retrieved from: http://www.scielo.org.mx/pdf/peni/v9n1/v9n1a1.pdf

Fundación Promigas (2010). Educación propia: una experiencia de construcción colectiva con comunidades wayuu. Colombia: Editorial Fundación Promigas/Fundación Caminos de Identidad. Retrieved from: http://www.fundacionpromigas.com.co/wps/wcm/connect/43695f00445 f396685cdff82af99c9ea/EDUCACIONPROPIAWEB+\%282\%29.pdf?MOD=AJPERES

García Canclini, N. (2001). Culturas híbridas. Estrategias para entrar y salir de la modernidad. Barcelona: Paidós.

Gasché, J. (2004). "Hacia una propuesta curricular intercultural en un mundo global". Ponencia. In: Rodríguez, M. A. (comp.). Foro Latinoamericano de Interculturalidad, Educación y Ciudadanía. Cuetzalán, Mexico: SEP-CGEIB, Contracorriente, Observatorio Ciudadano de la Educación, FLAPE, pp. 177-200 
Community and the School. Elements for the Debate on the Indigenous Community School

Giménez, Gilberto (2000). "Identidades étnicas: estado de la cuestión”. In: Reina, Leticia. Los retos de la etnicidad en los Estados-nación del siglo XXI. Mexico: CIESAS, INI, Miguel Ángel Porrúa.

(2009). "Cultura, identidad y memoria: Materiales para una sociología de los procesos culturales en las franjas fronterizas". Frontera norte, 21(41), 7-32. Retrieved from: http://www.scielo.org.mx/scielo.php?script=sci_arttext\&pid=S0187-73722009000100001\&lng=es\&tlng=es

González Apodaca, E. (2006). "Etnicidad, intermediación y escuela: tres iniciativas de bachillerato intercultural en la región mixe". Doctoral thesis. Mexico: UAM-Ixtapalapa.

— and A. Rojas (2013) "Proyectos locales, autonomía educativa y resistencia indígena". In: Bertely, M., G. Dietz and G. Díaz Tepepa (coords.). Multiculturalismo y Educación 2002-2011. Col. Estados de conocimiento, ANUIES, COMIE, pp. 383-413.

Hamel, R. (2001). Políticas del lenguaje y educación indígena en México. Orientaciones culturales y estrategias pedagógicas en una época de globalización. In: Bein, R. and J. Born (eds.). Políticas lingüísticas. Norma e identidad. Buenos Aires: UBA, pp. 143-170.

Jiménez Naranjo, Y. (2009). Cultura comunitaria y escuela intercultural. Mexico: CGEIB, SEP.

— (2012). "Cultura escolar y cultura comunitaria: una perspectiva intercultural en la construcción curricular". Lecture presented at IAIE. Veracruz.

Korsbaek, L. and Samano-Rentería, M. (2007). El indigenismo en México: antecedentes y actualidad. Ra Ximhai 3(1), 195-224. Retrieved from: www.ejournal.unam.mx/rxm/vol03-01/ RXM003000109.pdf

Lave, J. and E. Wenger (1991). Situated Learning. Legitimate Peripheral Participation. New York: Cambridge University Press.

Leff, E. (2004). Racionalidad ambiental. La reapropiación social de la naturaleza. Mexico: Siglo XXI.

López Pérez, A. (2004). "Individuo y comunidad: imágenes identitarias y tejidos culturales en los proyectos educativos de México". In: Gómez Sollano, M. and B. Orozco (2004). Espacios Imaginarios y sujetos de la Educación en la. Transición Epocal. Mexico: Plaza y Valdés, pp.189-218.

Maldonado, B. (2010). "Comunidad, comunalidad y colonialismo en Oaxaca, México. La nueva educación comunitaria y su contexto". Doctoral thesis. Netherlands: Universiteit Leiden.

Martínez Luna, J. (2010). "Cotidianidad y comunalidad”. Homo Erectus. Revista de educación y cultura política, año 1, (1) 21-25

— (2013). "Textos sobre el camino andado". Tomo 1. Oaxaca: CAMPO-CSEIIO-CMPIO-PLAN PILOTO-CNEII-CEEESCI.

Martínez Buenabad, E. (2015). "La educación intercultural y bilingüe (EIB) en México. ¿El camino hacia la construcción de una ciudadanía democrática?" Revista Relaciones (141) 103-131 Retrieved from: http://www.colmich.edu.mx/relaciones25/files/revistas/141/pdf/05_Elizabeth_Martinez.pdf 
Mato, D. (2008). "No hay saber 'universal', la colaboración intercultural es imprescindible". Alteridades, 18 (35) 101-116. Mexico: UAM-Iztapalapa.

Pieck, E., G. Messina y Colectivo docente (2008). Nuestras historias. El lugar del trabajo en las Telesecundarias Vinculadas con la Comunidad. Mexico: Universidad Iberoamericana.

PRATEC (2004). Una escuela amable con el saber local. Peru: PRATEC. Retrieved from: http:// www.pratecnet.org/pdfs/Una\%20escuela\%20amable.pdf

Rendón Monzón, J. J. (ed.) (2003). La comunalidad. Modo de vida en los pueblos indios. México: CONACULTA, pp. 91-108.

- (2011). La flor comunal. Explicaciones para interpretar su contenido y comprender la importancia de la vida comunal de los pueblos indios. Oaxaca: CNEII, CMPIO, CEEESCI, CSEIIO.

Rengifo, G. (2003). La enseñanza es estar contento. Educación y afirmación cultural andina. Lima. Peru: PRATEC/ Proyecto Andino de Tecnologías Campesinas.

Richard, N. (1993). "Alteridad y descentramiento culturales". Revista Chilena de Literatura, (42) 209-215. Chile: Universidad de Chile. Retrieved from: http://19bienal.fundacionpaiz.org.gt/ wp-content/uploads/2014/02/Nelly-Richard-Alteridad-y-descentramiento-culturales.pdf

Rockwell, E. (2005). La apropiación, un proceso entre muchos que ocurren en ámbitos escolares. In: Memoria, conocimiento y utopía. Anuario de la Sociedad Mexicana de Historia de la Educación. (1) 28-38. Barcelona: Pomares.

— (2011). "La experiencia etnográfica”. Buenos Aires: Paidós.

Roy, K. (2003). Teachers in Nomadic Spaces: Deleuze and Curriculum. New York: Peter Lang.

Sagástegui, D. (2004). “Una apuesta por la cultura: el aprendizaje situado”. Sinéctica (24), pp. 3039.

Santos, B. (2007). "Beyond Abyssal Thinking: From Global Lines to Ecologies of Knowledges". Review. Retrieved from: http://www.boaventuradesousasantos.pt/media/Beyond_Abyssal_ Thinking_Review_2007.pdf

- (2009). Descolonizar el saber, reinventar el poder. Montevideo: Trilce.

— (2010). Para descolonizar Occidente: más allá del pensamiento abismal. Buenos Aires: CLACSO/Prometeo Libros.

Sartorello, S. (2009). "Una perspectiva crítica sobre interculturalidad y educación intercultural bilingüe: El caso de la Unión de Maestros de la Nueva Educación para México (UNEM) y educadores independientes en Chiapas". Revista Latinoamericana de Educación Inclusiva, 3(2), pp. 77-90. Retrieved from: http://www.rinace.net/rlei/numeros/vol3-num2/art5.pdf

Silva, T. (1997). "Descolonizar el currículo. Estrategias para una pedagogía crítica". Revista Crítica Educativa. Año II (2), Buenos Aires.

Tovar, M. (2009). "Interculturalidad y epistemología". Lecture at the II Congreso Internacional y VII Seminario Nacional de Investigación en Educación, Pedagogía y Formación Docente. Medellín: Universidad de Antioquia/Universidad Pedagógica Nacional de Colombia. Retrie- 
Community and the School. Elements for the Debate on the Indigenous Community School

ved from: http://cursos.campusvirtualsp.org/pluginfile.php/3251/mod_page/content/1/determinantes/bibliocomplementaria/unidad_3.1bc/ud31bc_interculturalidad_y_epistemologia_ MTovar.pdf

Tyack, D. and L. Cuban (1995). Tinkering Towards Utopia: A Century of Public School Reform. Cambridge: Harvard University Press

Velasco, H. and A. Díaz de Rada (1997). La lógica de la investigación etnográfica. Un modelo de trabajo para etnógrafos de escuela. Madrid: Trotta.

Velasco, S. and A. Jablonska (coord.) (2010). Construcción de políticas educativas interculturales en México: debates, tendencias, problemas, desafios. Mexico: UPN.

Viaña, J. (2008). Reconceptualizando la interculturalidad. In: Mora, D. and S. De Alarcón. Investigar y Transformar. Reflexiones sociocríticas para pensar la educación. La Paz: Instituto Internacional de Integración, pp. 293-344.

Walsh, C. (2005). La interculturalidad en la educación. Peru: Ministerio de Educación/UNICEF. 